\title{
GRASSROOTS AND INHIBITORS ON RADICALISATION IN NORTH MACEDONIA: TOWARDS A SYSTEMIC APPROACH
}

\author{
UDC 355.216-055.2(497.17) \\ 314.74
}

\author{
Vesna Poposka \\ Macedonian Military Academy, Skopje, North Macedonia
}

\begin{abstract}
A few years ago, as migrant crisis was intensifying and the conflict in Syria was escalating, North Macedonia did not remain immune to the foreign fighter's phenomena. This was quite a surprise for the society as a whole. Although there were no official data, in 2018 media sources reported that it was approximated that between 75 and 90 Macedonian citizens joined the ISIS (Islamic State of Iraq and Syria), whereby women make a significant percentage of this group. Another media source reported that the total unofficial number of recruited Macedonian citizens was 156, nine of whom are women; 83 persons are said to have returned to the country. In 2017, the Republic of Macedonia adopted the National strategy for Countering Violent Extremism (CVE) and the National Counterterrorism Strategy (CT) but these two strategies lack the gender perspective on these issues. Women's engagement in these processes is a result of joint impact of different societal factors and variables. The paper aims to examine and provide deeper analysis of the current situation and most significant grassroot initiatives, which will be used as the basis for recommendations for improvement.
\end{abstract}

Key words: gender, radicalization, extremism, women

\section{INTRODUCTION AND METHODOLOGY}

The dissolution of Yugoslavia marked the dissolution of dream about "brotherhood and unity". Although in that period Macedonia was known as the "cradle of peace" and a highly tolerant society, the processes that followed took their toll. Global trends and dynamic developments did not bypass the whole region. The migrant crisis, geopolitical position, instability of the region, globalization of threats, as well as Macedonian support for the Global Coalition against Daesh in Afghanistan and Iraq, brought the foreign fighters phenomena in the focus. Stories were different and although they have been re-told, they

Received May $17^{\text {th }}, 2019 /$ Accepted July $22^{\text {nd }}, 2019$

Corresponding author: Vesna Poposka, LL.M. in International Law from the Faculty of Law "Iustinianus Primus", University of Skopje, is a PhD candidate of International Relations and Security Studies at the Macedonian Military Academy. She is junior academic staff of International Vision University; E-mail: vpoposka88@ gmail.com 
remained a "public secret" for some time. Although everyone says that radicalization is a great threat, no one goes deeper. Besides, this type of radicalization is not the only one in Macedonia, which has faced multiple protests and counter-protest, as well as two bloody attacks on the Macedonian Parliament (on $24^{\text {th }}$ December 2012 and on $24^{\text {th }}$ April 2017), in the periods of political crisis.

Gender perspective in this context has not been examined so far, which was the basic motivation for conducting research on this issue, including the risk of failing in the attempt. Yet, it is the responsibility of the academic community to address the problems that have been placed on hold or "under the rug". The primary idea was to focus on legal and policy framework only; however, the quest provided very few answers, particularly considering that the National Strategy on Countering Violent Extremism and Terrorism (NS CVET), adopted in 2017, lacks gender perspective on these issues. As the problem proved to be much wider, it was necessary to explore the social context, which was predominantly done by analyzing media coverage of relevant events. It should be noted that a separate research could be done on each of the headlines in this paper. If that happens, it means that this initial research was successful enough to provoke greater interest in the field. The research aims to examine whether the general concept of NS CVET policy is applied in Macedonian legal and policy framework. The main hypothesis of the research is that radicalization of women in North Macedonia is a result of complex political, economic and social factors. Additional hypothesis is that the lack of gender mainstreaming in the NS CVET efforts may lead to increased rate of radicalization among women and girls.

\section{BACKGROUND AND CONTEXTUALISATION}

The Balkan region has gone through the painful economic and political transition from socialism and monoparty system to a free market and plural democracy. The former still has a significant impact in the collective and individual memories. A society predominantly crafted in the manner of collective ownership and identity (a feature that is closer to the eastern rather than to the western mentality), with huge social stability and strong political system, suddenly had to overthrow the obtained identity and turn into capitalism and democracy. This process was accompanied by bloody ethnical conflicts, strong pressure of populism, and usage of nationalism and nation-building as part of the political agenda of the elites. The elites were probably the fastest shifters in the new society: they changed shape and rhetorics but still imposed the same mental code and promises to fuel the expectations of the masses.

After the peaceful dissolution from Yugoslavia, the former Socialist Republic of Macedonia obtained independence, but it faced more challenges than opportunities. Located in the heart of Balkan along the important Roman military road Via Egnatia, the petite landlocked country was permanently experiencing crises, both social and economic but predominantly political ones. Complicated ethnic and religious structure, limited resources, imposed economic embargos, relationships within the neighbors, the name issue (etc.) caused permanent troubles. The spillover effect of the wars and different processes in the region was also inevitable.

In theory, the political system in North Macedonia is based on pluralism but, in reality, the political scene is completely monopolized and divided, thus enabling the creation of parallel societies. The main mobilization factor is the political party; there is a 
lack of citizens' activism, and sustainable and influential social movements. Authentic social movements managed to come to the fore only on rare occasions, such as the protests against police brutality in June 2011. The civil sector is mainly divided or associated with one or another political option. There are three main schisms in society: the first and predominant one is affiliation or non-affiliation with a specific political party; the second one is ethnicity, and the third one is religion. Yet, the great anti-governmental rally on 17 May 2015 managed to unite almost all of the different societal groups. The current social democratic government has brought hope for a new beginning.

\section{THE FOREIGN FIGHTERS PHENOMENA}

A few years ago, as migrant crisis was intensifying and the conflict in Syria was escalating, North Macedonia did not remain immune to the foreign fighter's phenomena. This was quite a surprise for the society as a whole. The presence of the Muslim population in the region is not a newly planted idea or phenomenon. Although the Muslim population it is not homogenous (ethnically speaking), it is part of the common cultural heritage from the Ottoman times. Most of the Muslims in Macedonia have been living here for generations, which is not the case with Muslims in Western Europe.

In North Macedonia, Islam is mostly considered to follow the Hanafi school of thought (Petrović, 2016: 1). The Ottoman influence is still present in the culture and does represent an important part of the common history of all Macedonian citizens. Suffism also plays a significant role. In the western part of the country, there a few strong dervish communities. The Bektashi order of Dervishes is a Sufi order, belonging to neither the Sunni nor the Shi'a denominations, which most of Islam is divided into. Like all Dervish orders, the Bektashi see themselves as the doorkeepers, or servants of God. The order was founded almost 800 years ago by the Islamic mystic Hajji Bektash Wali and has remained autonomous within Islam as one of the largest and oldest of the Dervish orders (The Economist, 2013) ${ }^{1}$.

The first contact of the Balkan Muslims with the radical Islamists was established in the early 1990s during the war in Bosnia. However, this was not addressed as a potential security threat until recent, when the region was pointed out as a place of recruitment of foreign fighters for the battlefields of the Islamic State of Iraq and Syria (ISIS) (Metodieva, 2018: 4). In 2018, media reported that "at least 5 Macedonian women of Albanian ethnic origin have joined the ISIS in the last three years, as revealed by national security services" (Express.mk, 2017) ${ }^{2}$. Although there are no official data on this matter, same media sources reported that it is approximated that between 75 and 90 Macedonian citizens joined the ISIS, and that women make a significant percentage of this group. Another media source reported that the total unofficial number was 156 people, nine of whom were women, whereas 83 of them already returned to the country; notably, the number of recruited persons was significantly reduced after amending the Macedonian Criminal Code in 2014 (24vakti, 2018). ${ }^{3}$ In the first quarter of 2018, the public was shocked by the information that

\footnotetext{
${ }^{1}$ The Economist (2013): Baba mondi of a little known Suffi order with deep roots in the Ottoman Empire, available at https://www.economist.com/eastern-approaches/2013/09/23/baba-mondi

2 Express.mk (2017). Најмалку 5 жени од Македонија во ИСИС, една Македонка се вратила дома, published18 July2017, https://expres.mk...

24vakti.mk (2018). Во ИСИС активно се борат 15 македонски државјани,|24vakti.mk, 10 August 2018. available at https://24vakti.mk....
} 
a teenage girl from Kumanovo died in the battlefields in Syria; her father said that her behavior had changed after meeting a boyfriend through the social media (Brif.mk, 2015) ${ }^{4}$. Another media source reported on interviews with police experts from the Ministry of Interior (MoI) who said that the main reason for the radicalization of youth is the socioeconomic factor, i.e poverty, but there are also other factors: non-inclusion in the society, the education system that should act on raising awareness, family relations, peer pressure, as well as the nationalist euphoria such as the war that took place in 2001. According to the MoI findings, all of the recruited young people were persons of a low socio-economic status, and only a few of them were from higher classes. They have mainly been misled by ideology; they believe in what they do, and they think they are doing something good. Notably, some them have already returned to Macedonia and have been prosecuted under the new legislation which prescribes a term of imprisonment of at least five years for participation in foreign extremist and terrorist organisations (Lokalno.mk, 2018). ${ }^{5}$ An imam from Tutunsuz mosque in Skopje was sentenced to seven years imprisonment for radicalization and recruitment of soldiers in Macedonia (Lider.mk, 2018) ${ }^{6}$

\section{THE ROLE OF RELIGIOUS COMMUNITY}

The Islamic Religious Community in the country has been on the top news for a longer period, especially due to the political interference and the open clash with the Bektashi community. The case was mostly about the ownership of Arabati Baba Tekke near Tetovo, the sanctuary that belonged to the Bektashi community since the $15^{\text {th }}$ century. However, after the denationalization process, the state gave it to the Islamic Religious Community in Macedonia. This object was referred by some scholars as the frontline of confrontation with the Wahhabism. For the sake of truth, the Islamic Religious Community alarmed that they do not have control in four mosques in the country, while the daily newspaper "Dnevnik" reported that the fifth one is the mosque in Idrizovo. They asked the Ministry of Interior for help on several occasions (Radio Slobodna Evropa, 2011). ${ }^{7}$ On one occasion, the Ministry of Interior replied that the reis of the Islamic Community made sensationalist claims, but that the security services have pretty limited authorities under the positive law. The headquarters of the Islamic Religious Community were occupied for 12 days and the reis had to fulfill his duties from the menderesa in Kondovo after the relationships with the muftiship of Skopje came out of control (Kanal 5, 2015) ${ }^{8}$ This goes back in time. In 2005, there was also a power struggle within the Islamic Community, when the reis withdrew from the position. Each side blames another for radical interference.

\footnotetext{
${ }^{4}$ Brif. mk (2015). Керка на бизнисмен од Куманово неколку месеци војува за ИСИС, published 23 July 2015. https://www.brif.mk/kerka-na-biznismen-od-kumanovonekolk/?utm_source=daily.mk\&utm_medium $=$ daily.mk

${ }^{5}$ Lokalno.mk. (2018)“Сромаштијата младите ги прави лесен плен на радикализмот”, 4 March 2018 , http://lokalno.mk/siromashtijata-mladite-gi-pravi-lesen-plen-na-radikalizmot/

${ }^{6}$ Lider.mk (2018) Борците на ИД што ги депортираа САД, биле радикализирани од имамот од Чаир, 12. 08. 2018, https://lider.com.mk/makedonija/borcite-na-id-shto-gi-deportiraa-sad-bile-radikalizirani-od-imamot-od-chair/

${ }^{7}$ Radio Slobodna Evropa (2011): Гаџовска Спасовска, 3. “Помирување во ИВ3?”, published 17 Dec. 2011, available at https://www.slobodnaevropa.mk/a/24434717.html

${ }^{8}$ Kanal 5 (2015). ИВ3 останува поделена и за Рамазан, published 17 јуни 2015,-available at https://kanal5. com.mk/articles/236945/ivz-ostanuva-podelena-i-za-ramazam
} 


\section{SOCIAL AND ECONOMIC DEPRIVATION AND POLITICAL SCHISM}

The Macedonian society is highly polarized although the potential for active conflict is low. After 12 years of having the conservative government, the country is still recovering from the effects of its nationalist politics. The incapacity of the institutions to bring criminal elites to justice still reverberates in the society, especially after the former Prime Minister Gruevski fled the coutry in November 2018 seeking political asylym in Hungary while his party split in two fractions. In the face of the Prespa Agreement with Greece over the name of the county, there were antigovernment protests on a daily basis. ${ }^{9}$ The last decade has been marked by the creation of parallel societies in the country. Every protest was followed by a counter-protest, ending up with the conclusion the other side was to be blamed for everything that was wrong. The mutual blame-pinning practices soon became the subject matter of parody.

The main political parties, the ruling SDSM (Social Democratic Union) and the conservative opposition VMRO-DPMNE (Internal Macedonian Revolutionary OrganizationDemocratic Party for Macedonian National Unity), forefront the coalitions including a bunch of smaller parties, mainly based on ethnicity (Albanians, Turks, Serbs, Roma, etc.). However, each ethnicity is further divided along the party lines, as each ethnicity includes members of the two major parties: one in power and one in the opposition. For this reason, patriotism and nationalism are usually used as a cover for power-sharing and, more importantly, interestsharing. A common issue for almost all political parties is North Macedonia is the role of women organization within the party and election of female representatives for leading positions, which is completely minor. However, the good news is that Macedonia has finally resolved the name issue and received a positive report and clear recommendation to join the EU, which is about to bring new perspectives and dynamics.

\section{MACEDONIAN SOCIETY THROUGH FEMALE LENSES}

As most of the Balkan countries, the country has been facing high migration rates. Although the official census has not been conducted for 15 years, unofficial data show that more than half a million citizens left Macedonia since it gained independence 25 years ago (The Economist, 2017) ${ }^{10}$. People usually explain this trend by the economic situation, poor living standard and quality of life, inadequate social welfare, health care and education system, lack of opportunities, and lately high air pollution. The fact is that all of these reasons affect women much more. The country lacks an adequate social welfare and health care system which would address the needs of all, especially women. For example, there is a lack of daily centers for people with disabilities so that at least one parent (usually the mother) has to remain at home to take care of the disabled person, even when he/she is already an adult. Kindergartens, pre-school and day-care facilities where children can stay during the parents' working hours are overcrowded so that children are most frequently minded by mothers or grandparents. As there is gender-based wage gap, mothers are usually the ones who stay at home when a member of the family is in need (Alsat-M,

\footnotetext{
9 OBC Transeuropa (2018) :I. Cvetanoski, Macedonia, the Gruevski's escape, puslished 20.11.2018, https://www.balcanicaucaso.org/eng/Areas/North-Macedonia/Macedonia-the-Gruevski-s-escape-191277

${ }^{10}$ The Economist (2017): Macedonian emigrants estimated at more than $30 \%$ of population, published 28 Feb.2017, available at http://country.eiu.com/article.aspx?..
} 
2017) ${ }^{11}$. The conditions in public hospitals, especially at gynecology wards, are quite miserable, particularly in smaller towns and rural areas. The new government has been trying to improve the situation. Women do participate actively in all societal spheres but the problem is that they rarely manage to take decision-making positions. The decade-long public narrative of the previous government coalition forefronted by the conservatives imposed a huge burden of chauvinism and nationalism. It culminated in the so-called cultural project "Skopje 2014", an attempt to assert Macedonia's identity through "antiquitisation" (decorating the Skopje city center monuments recalling the glorious past of Alexander the Great). Notably, among hundereds of masculine sculptures of warriors, there are only a few female figures, while the central one represents Olympia breastfeeding Alexander the Great. During that period, many public campaigns were funded from the budget and conducted with similar machoism narratives. That trend created huge social revolt against social injustice, corruption and impunity of the ruling conservative elite. Women were leading many of the mass peaceful protests in the so-called "Colorful revolution" for freedom, justice and equality (Meta.mk, 2016) ${ }^{12}$.

\section{GENDER PERSPECTIVE In COUNTERING VIOLENT EXTREMISM AND RADICALISATION}

The year 2017 was a cornerstone for official centralized activities in the field of preventing radical extremism and fight against terrorism in Macedonia. The National Committee for Countering Violent Extremism and Countering Terrorism (NC CVECT) was established by a Government decision on establishing the National Committee (Official Gazette 98/2017). ${ }^{13}$ The National Coordinator and two deputies were appointed by another governmental decision. The first task of the Committee was to prepare the National Strategy of the Republic of Macedonia for Countering Violent Extremism (CVE) ${ }^{14}$ and the National Counterterrorism Strategy (CT) (2018-2022) ${ }^{15}$, with accompanying action plans. Both strategies are strategic and synergetic documents resting on common grounds. They imply holistic approach to preventing and counteracting violent extremism and counterterrorism at the local, national, and international levels. The prefaces to both documents end with the slogan: "Strong families, strong communities, strong society". The strategies clearly address the needs of all the citizens, but neither of them includes genderrelated issues or gender-specific perspective. In the key terms and definitions, the strategies recognize "At-risk people: People who are particularly vulnerable to becoming radicalized to violent extremism. A number of factors can make people vulnerable to radicalization,

\footnotetext{
${ }^{11}$ ALSAT-M (2017). F. F.Veseli, Дури 46 отсто од жените во Македонија не се дел од пазарот на трудот, 30.01. 2017., https://www.alsat-m.tv/mk/...

${ }_{12}$ Meta.mk (2016) „Шарена револуција“: Вие кривични, ние похрабри, published 4.June 2016, https://meta.mk/sharena-revolutsija-vie-krivichni-nie-pohrabri/

${ }^{13}$ Одлука за формирање на Национален комитет за спречување на насилен екстремизам и борба против тероризам, Влада на Република Македонија, Службен весник на РМ““ бр. 98/2017,

http://www.slvesnik.com.mk/Issues/396f0f904d6a4151aa9595d441b6a903.pdf

${ }^{14}$ National Strategy of the Republic of Macedonia for Countering Violent Extremism (CVE), Skopje, 15. 02. 2018, https://www.rcc.int/p-cve/docs/196/national-strategy-of-the-republic-of-north-macedonia-for-counteringviolent-extremism-2018

${ }^{15}$ National Counterterrorism Strategy (CT)of the Republic of Macedonia (2018-2022) ,Skopje, 27. February 2018; Government of the Republic of Macedonia, National Committee for Countering Violent Extremism and Countering Terrorism; available at

https://vlada.mk/sites/default/files/dokumenti/ct_national_strategy_eng_translation_sbu.pdf
} 
including the exclusion from the family, friends or the broader community, and exposure to criminality or violence." (NS CVE/CT, 2018: 14). Sticking to a broad definition is probably appropriate for a society such as Macedonia, where different groups easily interfere into sensitive social developments. The specific goals of preventing and counteracting violent extremism and terrorism include (NS CVE/CT, 2018: 30):

\section{Prevent}

Strategic goal 1.1: Strengthened institutional capacities

Strategic goal 1.2: Raising public awareness

Strategic goal 1.3: Strong and resistant community Strategic goal

Strategic goal 1.4: Preventing radicalization via Internet

\section{Protect}

Strategic goal 2.1: Proactive institutions in the context of protection of the basic values, human rights and freedoms

Strategic goal 2.2: Increasing the confidence among relevant institutions and citizens for protection against radicalization and violent extremism

\section{Pursue}

Strategic goal 3.1: Established set of measures for early detection of radicalization

\section{Respond}

Strategic goal 4.1: Deradicalization

Strategic goal 4.2: Reintegration thru resocialization

Within the presented research, the author of this article conducted an interview with the National Coordinator in order to discuss the two strategies and gender-related issues. The National Committee (CVECT) does not have a gender advisor, but gender expertise is not the only shortcoming. The idea is to have different specialist for different target groups on specific questions. The broad language of the two strategies is used due to sensitivity toward different groups and various forms of radicalization within the society. Their approach is soft and focused on prevention. They envisage state cooperation with civil society and religious institutions in order to build trust among institutions and people at risk. Currently, several main activities are underway: working on a project for developing counter-narratives (messaging and alternative view to extremist recruitment and propaganda) and communication strategy (although it is mainly focused on the Committee activities and it does not include gender-related issues or narratives for women); engagement in international activities and training; preparing a forum for dialogue with representatives of religious institutions within the country; and working with municipalities (MIA, 2018). ${ }^{16}$ The activities also include organizing local panels and focus groups. Notably, a photo from such a discussion held in Struga shows that participants are predominately women (Spektra, 2018). ${ }^{17}$ Another project "Mother Schools for Counteracting Radicalism" was implemented from November 2016 to March 2017 by the civil society organisation "Women to Women", in cooperation with Women without Borders (Analyticamk.org). ${ }^{18}$ The project included women

\footnotetext{
${ }^{16}$ МІА (2018): Стефановска, С. Меморандум за проектот „Јакнење на отпорноста од насилен екстремизам на локалните заедници во Македонија“, МИА, available at https://mia.mk/2018/10/memorandum-za-proektot-akne-ena-otpornosta-od-nasilen-ekstremizam-na-lokalnite-zaednici-vo-makedoni-a (accessed 15.May 2019)

17 Spectra (2018): Општина Струга: “Дебата за спречување на насилен екстремизам и борба против тероризам”, 6.11.2018, available at http://www.spektra.com.mk/lokalni/opshtina-struga-debata-za-sprecuvanjena-nasilen-ekstremizam-i-borba-protiv-terorizam

${ }_{18}$ Analyticamk.org: CSO Analytica Think Tank: "Mother Schools Project for Countering Radicalism" (not dated), available at https://www.analyticamk.org/en/programs/foreign-and-security-policy/631-mothers-schools-project
} 
in a few municipalities of the City of Skopje and it was aimed at raising awareness and training women (mothers and wives) whose children or relatives have been exposed to radicalization or have gone to the ISIS battlefields, developing their competences to deal with these issues, and empowering them to build a community-based security strategy to counter radical ideologies (Stojkovski, Selimi, 2018:11).

The National Committee (CVECT) is not the only institution lacking gender perspective. The Ministry of Defense and the Ministry of Interior do not have gender advisors, nor are they available to officers deployed in international missions. The last national action plan (NAP) on the UN Security Council Resolution UNSCR 1325 is quite vague and theoretical. The UN Security Council Resolution UNSCR 2242 called for the inclusion of women in devising CVE programmes but the broad women and security agenda of the Macedonian Ministry of Defence ${ }^{19}$ does not even mention the UN SCR 2242. The UN Secretary-General's 2016 Plan of Action on Preventing Violent Extremism ${ }^{20}$ included a pillar dedicated to the role of women and girls. It urged member states to mainstream gender perspectives, empower women and strive for gender equality. However, none of these documents has been referred to in the official Macedonian policy documents.

\section{CONCLUSIONS AND RECOMMENDATIONS}

It is generally accepted that women can play critical roles in developing responses to violence and terrorism, and challenging and delegitimizing extremist narratives. Women can be powerful agents of change, and they can even play a crucial role in detecting early signs of radicalization and intervening before individuals become violent. Understanding these varied roles of women is critical to developing more nuanced and targeted efforts to counter violent extremism and prevent terrorism (Commonwealth.org, 2018). ${ }^{21}$

However, the problem with CVE and CT efforts in North Macedonia is wider.

First, there is a lack of institutional approach and awareness about gender dimension, which is contrary to all policy recommendations. Institutions need to take more interest in this issue. For example, different $\mathrm{CoE}$ initiatives have hardly been referred to or used $(\mathrm{CoE}$, $2018)^{22}$

Second, women in North Macedonia are quite a diversified category, although they share most of the everyday-life problems: poor quality of life, economic deprivation, underdeveloped infrastructure, chaotic administration, inadequate social welfare system and health care, high air pollution, etc. North Macedonia is a multiethnic society and every local community has different customs and rituals that are generally accepted or recommended as preferred form of conduct. Specific subgroups need specific targeting and specific

\footnotetext{
19 Ministerstvo za odbrana (MO), Родова рамноправност и родова перспектива во одбраната и во безбедноста, Sovremena makedonska odbrana, Vol. 13/Ministry of Defence of R.Macedonia, Gender Equality and Gender Perspective in Defence and Security, Contemporary Macedonian Defence,Vol.13, Skopje, 2013, ISSN 1409-8199

${ }^{20}$ The UN Secertary-General's Plan of Action on Preventing Violent Extremism (2016), UN Counterterorism Office, https://www.un.org/counterterrorism/ctitf/en/plan-action-prevent-violent-extremism

${ }^{21}$ The Comomwealth.org (2018): Countering Violent Extremism Toolkits, available at http://thecommonwealth.org/ countering-violent-extremism-toolkits

${ }^{22}$ See: Council of Europe (2018): "Fight against violent extremism and radicalisation leading to terrorism" Implementing the Action Plan Final Report of the Secretary General, available at https://rm.coe.int/sg-inf-20187-fight-against-violent-extremism-and-radicalisation-leadi/16807c0d4b
} 
approach: for example, although they encounter similar problems, rural women from the eastern parts of Macedonia need a different approach than rural women from the western parts of country.

Third, the fact that two national strategies are focused on resilience means that this society needs empowered women, since resilient society cannot be established within vulnerable groups.

Fourth, North Macedonian society needs better visibility of female role models. A good example is the establishment of database of female experts ${ }^{23}$.

Fifth, institutions need to take seriously and implement effectively recommendations of the UN Security Council Resolution 2242 (UN SCR 2242/2015). Among other issues, the resolution urges Member States to ensure the participation and leadership of women and women's organizations in developing strategies to counter terrorism and violent extremism which can be conducive to terrorism, to counter incitement to commit terrorist acts, to create counter narratives and other appropriate interventions, to build their capacity in order to empower women, youth, religious and cultural leaders, to address the conditions conducive to the spread of terrorism and violent extremism which can be conducive to terrorism. It also asks member states to integrate gender as a cross-cutting issue throughout the activities within their respective mandates, including specific assessments and reports, which unfortunately has not been the case in North Macedonia. Gender advisors are a must, especially when planning peacekeeping missions abroad. A real National Action Plan (NAP) is needed for the implementation of UN Security Council Resolution 1325, as well as a wider peace and security agenda.

Sixth, there is a lack of trust and communication in the society: a lacks of trust in the system, institutions and different groups; a lack of communication among institutions, groups and political elites. Unfortunately, the greatest political decisions (such as the Przhino Agreement) were brought outside the system of formal institutions. In order to maintain trust, institutions (especially public administration) have to do their work much more efficiently and effectively. The country is facing high corruption rates in different areas (although official statistics show some improvement lately). The geopolitical position makes the country vulnerable to different forms of organized crime. Political and religious elites enjoy lower threshold of trust, especially women's organizations in parties as traditionally the greatest HR pool in the country (Nova Makedonija, 2019) ${ }^{24}$. The Special Public Prosecution Office also needs to deliver results.

Seventh, the building of counter-narratives needs a more systematic approach, clear definition of the messages aimed at to specific groups, as well as allocation of the most appropriate channels of communication with different groups. It requires wider expertise in the field of psychology, sociology, social work, psychiatry, pedagogy, and communicology. It also calls for building a wider network, including institutions, local authorities and true local leaders in prominent social positions (priests, school teachers, village elders, popular TV personalities, etc.). It also requires legal intervention, for example by enacting a set of media laws, in order to ensure that the program council of the national broadcaster_would take the problem into account.

\footnotetext{
${ }^{23}$ See: Database of female experts, project implemented by ednakvi.mk (2018); http://ekspertki.ednakvi.mk/

${ }^{24}$ Nova Makedonija (2019): Павловска, J. (2018) “Довербата-алката што се кине меѓу граѓаните и политичарите", published 26. January 2019, available at https://www.novamakedonija.com.mk/makedonija/ politika/....(accessed 15.May 2019)
} 
Eight, the society and individuals are in need to relax and withdraw from the negative matrix, which may be illustrated by the information that an increased use of antidepressant has been registered since 2014 , by almost $50 \%$ of the population (A1onMK, 2014) ${ }^{25}$. Poor living standard and quality of life affect all generations in different manner.

Ninth, the overall treatment of smaller constitutional minorities (which are usually labeled as "less than 20") needs to improve. For example, the state funds primary and secondary education for each minority in their mother tongue but, when it comes to higher education, they may proceed education in their language only if they organize it on their own, which is a high threshold to be reached. Another issue is the Equitable Ethnic Representation system (the so-called "Balancer" system), which has been envisaged as a percentage-based model for diversity management at the workplace, ensuring equal opportunities to all non-majority groups and their balanced participation in the public life (EPI, 2016: 22$)^{26}$ Yet, it is also a huge challenge due to the noted lack of transparency in recruiting procedures, party-based recruitment and corrupt (negative-selection) practices which may be the key factors in deciding which ethnicity candidates may apply for a certain position in the public administration. For members of smaller ethnic communities, it is very hard to reach such positions.

In short, North Macedonia needs to stick to the recommendations of the Priebe Report (Senior Experts' Group assessment and recommendations on Rule of Law issues) (EC /SEG $2017)^{27}$ and implement reforms toward improving the resilience of the society as a whole. The government needs to allocate resources for further research, especially pertaining to women who have been radicalized and joined ISIS, but also to obtain deeper understanding of the situation in the field. Laws and regulations might be perfect on paper and the ratification of the Istanbul Convention is a great step ahead, but the key idea behind these activities is to put them into effect and make laws work. The process needs a systematic/systemic approach as well as political will, which should be reaffirmed within the political parties.

\section{REFERENCES}

Council of Europe (2018) Information Document SG/Inf(2018): "Fight against violent extremism and radicalisation leading to terrorism" - Implementing the Action Plan Final Report of the Secretary General, available at https://rm.coe.int/sg-inf-2018-7-fight-against-violent-extremism-and-radicalisation-leadi/16807c0d4b (accessed 10 May 2019)

The Commonwealth.org database (2018): Countering Violent Extremism Toolkits, available at http://thecommonwealth.org/countering-violent-extremism-toolkits (accessed 10 May 2019)

European Commission (SEG Report 2017): The former Yugoslav Republic of Macedonia: Assessment and recommendations of the Senior Experts' Group on systemic Rule of Law issues, Brussels, 14 September 2017; available at https://ec.europa.eu/neighbourhood-enlargement/sites/near/files/2017.09.14_seg_report_ on_systemic_rol_issues_for_publication.pdf

European Policy Institute (2016). LIFE AND NUMBERS : Equitable ethnic representation and integration at the workplace /[authors Malinka Ristevska Jordanova.... [и др.], EPI, Skopje, 2016, available at http://www.epi.org.mk/docs/Life\%20and\%20numbers_ENG_Final\%20version.pdf

\footnotetext{
${ }^{25}$ AlonMK (2014): “ФЗОМ: зголемена употреба на антидепресиви”, published 4.11.2014, available at https://a1 on.mk/archives/404876

${ }^{26}$ For more, see: European Policy Institute (EPI), 2016. LIFE and numbers : equitable ethnic representation and integration at the workplace / [authors Malinka Ristevska Jordanova...[и др.],, EPI, Skopje, March 2016,

27 See: European Commission (SEG Report 2017): The former Yugoslav Republic of Macedonia: Assessment and recommendations of the Senior Experts' Group on systemic Rule of Law issues, Brussels, 14 Septembar 2017; https://ec.europa.eu/neighbourhood-enlargement/sites/near/files/2017.09.14_seg_report_on_systemic_rol_issues _for_publication.pdf
} 
Former Yugoslav Republic of Macedonia: Assessment and recommendations of the Senior Experts' Group on systemic Rule of Law issues 2017, available at https://ec.europa.eu/neighbourhood-enlargement/sites/near/ files/2017.09.14_seg_report_on_systemic_rol_issues_for_publication.pdf

Metodieva, Asya (2018). Balkan Foreign Fighters Are Coming Back: What Should Be Done? Strategic Policy Institute, Policy paper, retrieved on 10 May 2019 from https://www.stratpol.sk/wp-content/uploads/2018/ 01/Metodieva_Returnees_Western_Balkans_Stratpol_FINAL.pdf

Ministerstvo za odbrana (MO), Родова рамноправност и родова перспектива во одбраната и во безбедноста, Sovremena makedonska odbrana, Vol. 13/Ministry of Defence of R.Macedonia, Gender Equality and Gender Perspective in Defence and Security, Contemporary Macedonian Defence, Vol.13, Skopje, 2013, available at http://www.morm.gov.mk/wp-content/uploads/2013/12/GENDER-EQUALITYAND-GENDER-PERSPECTIVE-IN-DEFENCE-AND-SECURITY.pdf

National Strategy of the Republic of Macedonia for countering violent extremism (2017) https://vlada.mk/sites/default/files/dokumenti/cve_national_strategy_eng translation_sbu.pdf

National Counterterrorism Strategy (2018-2022) of the Republic of Macedonia (2017), thttps://vlada.mk/sites/default/files/dokumenti/ct_national_strategy_eng_translation_sbu.pdf

Одлука за формирање на Национален комитет за спречување на насилен екстремизам и борба против тероризам, Влада на Република Македонија, „Службен весник на РМ““ бр. 98/2017, http://www.slvesnik.com.mk/Issues/396f0f904d6a4151aa9595d441b6a903.pdf

Petrović, Predrag (2016) Islamic radicalism in the Balkans, European Union Institute for Security Studies (EUISS), June 2016, available at https://wb-iisg.com/wp-content/uploads/bpattachments/4732/Alert_24_Balkan_radicalism.pdf

Schwartz, Stephen (2011). Notes on Sufism as a Social Movement, available at http://www.islamicpluralism. org/1797/notes-on-sufism-as-a-social-movement

Stojkovski, F. and Selimi S. (2018). Mapping Report: Civil Society in Preventing and Countering Violent Extremism in Macedonia, Centre for Common Ground, Skopje, Macedonia, available at https://organizingagainstve.org/mapping-report-civil-society-organizations-in-preventing-and-counteringviolent-extremism-in-the-western-balkans/(p 11)

United Nations Security Council Resolution UN SCR 2242/2015, available at https://www.securitycouncilreport. org/atf/cf/\%7B65BFCF9B-6D27-4E9C-8CD3-CF6E4FF96FF9\%7D/s_res_2242.pdf

\section{MEDIA SOURCES}

A1on MK (2014): “ФЗОМ: зголемена употреба на антидепресиви, published 4.11.2014, available at https://a1on.mk/archives/404876 (accessed on 15.May 2019)

ALSAT-M. (2017). F. Veseli, Дури 46 отсто од жените во Македонија не се дел од пазарот на трудот, 30. 01. 2017, (accessed on 15.May 2019), available at https://www.alsat-m.tv/mk/\%D0\%94\%D $1 \% 83 \%$ D1\%80\%D0\%B8-46-\%D0\%BE\%D1\%82\%D1\%81\%D1\%82\%D0\%BE-\%D0\%BE\%D0\%B4-\%D0\%B6\% D0\%B5\%D0\%BD\%D0\%B8\%D1\%82\%D0\%B5-\%D0\%B2\%D0\%BE-\%D0\%9C\%D0\%B0\%D0\%BA\% D0\%B5\%D0\%B4\%D0\%BE\%D0\%BD\%D0\%B8\%D1\%98\%D0\%B0-\%D0\%BD\%D0\%B5/

Brif. mk (2015). Керка на бизнисмен од Куманово неколку месеци војува за ИСИС, published July 23 , 2015, available at https://www.brif.mk/kerka-na-biznismen-od-kumanovo-nekolk/?utm_source=daily. mk\&utm_medium=daily.mk (accessed on 15.May 2019)

Ednakvi.mk (2018): Database of female experts, project implemented by ednakvi.mk, available at http://ekspertki.ednakvi.mk/(accessed on 15.May 2019)

The Economist (2013): Baba mondi of a little known Suffi order with deep roots in the Ottoman Empire, available at https://www.economist.com/eastern-approaches/2013/09/23/baba-mondi

The Economist (2017): Macedonian emigrants estimated at more than $30 \%$ of population, published 28 Feb.2017, accessed on 15.May 2019, available at http://country.eiu.com/article.aspx?articleid= $285169212 \&$ Country=Macedonia\&topic=Economy\&subtopic=Forecast\&subsubtopic=Economic + growth \& $\mathrm{u}=1 \&$ pid=307361214\&oid=307361214\&uid=1

Express.mk (2017). Најмалку 5 жени од Македонија во ИСИС, една Македонка се вратила дома, published 18 July 2017, accessed on 15.May 2019, available at https://expres.mk/\%D0\%BD\%D0\% B0\%D1\%98\%D0\%BC\%D0\%B0\%D0\%BB\%D0\%BA\%D1\%83-5-\%D0\%B6\%D0\%B5\%D0\%BD\%D0\% B8-\%D0\%BE\%D0\%B4-\%D0\%BC\%D0\%B0\%D0\%BA\%D0\%B5\%D0\%B4\%D0\%BE\%D0\%BD\%D0\% B8\%D1\%98\%D0\%B0-\%D0\%B2\%D0\%BE-\%D0\%B8\%D1\%81\%D0\%B8\%D1\%81-\%D0\%B5/

Lider.mk (2018): Борците на ИД што ги депортираа САД, биле радикализирани од имамот од Чаир, available at https://lider.com.mk/makedonija/borcite-na-id-shto-gi-deportiraa-sad-bile-radikalizirani-odimamot-od-chair/ (accessed on 15.May 2019) 
Lokalno.mk. (2018)“Сромаштијата младите ги прави лесен плен на радикализмот”, published 04/03/2018, http://lokalno.mk/siromashtijata-mladite-gi-pravi-lesen-plen-na-radikalizmot/ (accessed on 15.May 2019)

Kanal 5 (2015). ИВ3 останува поделена и за Рамазан, published 17 јуни 2015,-available at https://kanal5.com.mk/articles/236945/ivz-ostanuva-podelena-i-za-ramazam (accessed 10.5. 2019)

MIA (2018): С. Стефановска, Меморандум за проектот „Јакнење на отпорноста од насилен екстремизам на локалните заедници во Македонија“, МИА, 29 October 2018, available at https://mia.mk/2018/10/ memorandum-za-proektot-akne-e-na-otpornosta-od-nasilen-ekstremizam-na-lokalnite-zaednici-vomakedoni-a (accessed 15.May 2019)

Meta.mk (2016) „Шарена револуција“: Вие кривични, ние похрабри, published 4.June 2016, available at https://meta.mk/sharena-revolutsija-vie-krivichni-nie-pohrabri/ (accessed 15.May 2019)

Nova Makedonija (2019): Павловска, Ј.(2018) “Довербата-алката што се кине меѓу граѓаните и политичарите”, published 26. January 2019, accessed on 15.May 2019, available at https://www.novamakedonija. com.mk/makedonija/politika/\%D0\%B4\%D0\%BE\%D0\%B2\%D0\%B5\%D1\%80\%D0\%B1\%D0\%B0\%D1\%82\% D0\%B0-\%D0\%B0\%D0\%BB\%D0\%BA\%D0\%B0\%D1\%82\%D0\%B0-\%D1\% $88 \%$ D1\%82\%D0\%BE-\%D1\%81\%D0\%B5-\%D0\%BA\%D0\%B8\%D0\%BD\%D0\%B5-\%D0\%BC\%D0\%B5\% D1\%93\%D1\%83-\%D0\%B3\%D1\%80\%D0\%B0\%D1\%93/

OBC Transeuropa(2018): I. Cvetanoski, Macedonia, the Gruevski's escape, published 20.11.2018, https://www. balcanicaucaso.org/eng/Areas/North-Macedonia/Macedonia-the-Gruevski-s-escape-191277 (accessed 15.May 2019)

Radio Slobodna Evropa (2011): Гаџовска Спасовска, 3. “Помирување во ИВ3?” published 17 Dec. 2011, available at https://www.slobodnaevropa.mk/a/24434717.html (access 15.May 2019)

Spectra(2018). Општина Струга: Дебата за спречување на насилен екстремизам и борба против тероризам, published 6 November 2018; http://www.spektra.com.mk/lokalni/opshtina-struga-debata-zasprecuvanje-na-nasilen-ekstremizam-i-borba-protiv-terorizam (accessed 15.May 2019)

24vakti.mk : Memed, S. (2018). Во ИСИС активно се борат 15 македонски државјани, published 10.09. 2018, accessed 15.May 2019, available at https://24vakti.mk/\%D0\%B2\%D0\%BE-\%D0\%B8\%D1\%81\% D0\%B8\%D1\%81-\%D0\%B0\%D0\%BA\%D1\%82\%D0\%B8\%D0\%B2\%D0\%BD\%D0\%BE-\%D1\%81\% D0\%B5-\%D0\%B1\%D0\%BE\%D1\%80\%D0\%B0\%D1\%82-15-\%D0\%BC\%D0\%B0\%D0\%BA\%D0\% B5\%D0\%B4\%D0\%BE\%D0\%BD\%D1\%81\%D0\%BA\%D0\%B8-\%D0\%B

\section{INICIJATIVE LOKALNE ZAJEDNICE U POGLEDU SPREČAVANJA RADIKALIZACIJE U SEVERNOJ MAKEDONIJI: KA SISTEMSKOM PRISTUPU BORBI PROTIV NASILNOG EKSTREMIZMA I TERORIZMA}

Pre nekoliko godina, usled eskalacije sukoba u Siriji i jačanja migrantske krize, Severna Makedonija se suočila sa problemom radikalizacije i regrutovanja stranih boraca za potrebe Islamske države Iraka $i$ Sirije (ISIS). Iako nije bilo zvaničnih podataka, neki medijski izvori su navodili nezvanične procene da se između 75 i 90 makedonskih građana pridružilo ISIS-u. Drugi mediji su naveli nezvaničan podatak o ukupno 156 regrutovanih makedonskih državljana, među kojima je bilo i devet žena. Dok su mediji izveštavali o radikalizaciji, Republika Makedonija je 2017. godine usvojila Nacionalnu strategiju za borbu protiv nasilnog ekstremizma i Nacionalnu strategiju za borbu protiv terorizma. Međutim, očigledan je nedostatak rodne perspektive u ovim strategijama. Glavna hipoteza ovog istraživanja je da je radikalizacija žena i devojaka u Severnoj Makedoniji rezultat složenih političkih, ekonomskih $i$ društvenih faktora. Nedostatak rodne perspektive u Nacionalnoj strategiji za borbu protiv nasilnog ekstremizma i terorizma može dovesti do povećane stope radikalizacije žena. U radu se razmatra trenutno stanje, analizira primena Nacionalnih strategija i daju preporuke za poboljšanje trenutne situacije.

Ključne reči: rod, radikalizija, ekstremizam, žene

Proofreading, copy-editing and translation:

Gordana Ignjatovic, BA 